\title{
Assessment of the vulnerability of Venezuela to sea-level rise
}

\author{
María de Lourdes Olivo* \\ Dirección General Sectorial de Planificación y Ordenación del Ambiente, Ministerio del Ambiente y de los Recursos \\ Naturales Renovables, El Silencio, Centro Simón Bolívar, Torre Sur, piso 9, Caracas, Venezuela
}

\begin{abstract}
The goal of this study is to assess the vulnerability of 5 sectors of the coast of Venezuela to potential sea-level rise using the methodology proposed by the Intergovernmental Panel on Climate Change. Sea-level rise resulting from thermal expansion of the oceans and melting of glaciers is viewed as one of the main impacts of climate changes. A $0.5 \mathrm{~m}$ rise scenario for the year 2100 was used for this study. A modified version of the Brunn Rule was used to estimate land loss due to erosion. Land loss due to inundation was considered for the case of lowlands. According to the assessments performed, land loss due to erosion in the 5 coastal areas chosen for the study $\left(20.07 \mathrm{~km}^{2}\right)$ would be less than that due to inundation $\left(52.63 \mathrm{~km}^{2}\right)$. Oil infrastructure, urban areas, and tourist infrastructure, all of which are essential to the national economy, would be affected. The areas with more population at risk would be the Costa Oriental del Lago de Maracaibo (eastern coast of Maracaibo Lake) and Costa Oriental del Estado Falcón (eastern coast of Falcón State). The former has the highest capital value at risk, followed by Barcelona-Puerto La Cruz-Guanta. Assuming a 'No Protection' response and a $0.5 \mathrm{~m}$ sealevel rise, approximately $131.13 \mathrm{~km}^{2}$ would be lost. If the 'Important Areas Protection' option was implemented, only $86.16 \mathrm{~km}^{2}$ (US $\$ 15000$ million) would be lost. The vulnerability of these coastal areas could be reduced by more appropriate planning and management.
\end{abstract}

KEY WORDS: Venezuela $\cdot$ Climate change - Sea-level rise $\cdot$ Land loss · Coastal erosion - Coastal inundation

\section{INTRODUCTION}

Sea-level rise and its impacts on coastal areas are consequences of global warming which may adversely affect the coastal areas of many countries. The main effects of this phenomenon result in erosion and inundation problems, followed by a consequent coastline recession as well as loss of wetlands with rich biological diversity.

The coastline of Venezuela is approximately $4000 \mathrm{~km}$ long. Sixty-seven percent of this coastline is located on the Caribbean Sea, and $33 \%$ on the Atlantic Ocean. The coast stretches to the east up to the border with Guyana, and to the west up to the border with Colombia. The vast majority of the activities that are most relevant for the country's economy take place along the coast, namely those associated with urban centers, industries (particularly oil extraction and processing),

\footnotetext{
•E-mail: sotor@telcel.net.ve
}

tourism and fisheries. However, these activities are concentrated in a few intensively developed areas, which cover only about $13 \%$ of the coastline. The objective of this study is to perform a detailed assessment of the potential impacts of sea-level rise on five coastal sites of Venezuela.

\section{METHODS}

The 'Seven Steps for the Assessment of the Vulnerability of Coastal Areas to Sea Level Rise-A Common Methodology' (IPCC 1990) was applied. It includes the following: (1) delineation of the case study area; (2) inventory of the natural and socioeconomic system; (3) identification of relevant development factors; (4) assessment of physical changes and natural system responses; (5) formulation of response strategies and assessment of their costs; (6) assessment of the vulnerability; and (7) identification of needs and plan of action. 


\subsection{Study area}

A general assessment of the entire coastline at a scale of 1:100000 was performed. Five sites were further selected based on suggestions made by Arismendi \& Volonté (1992). Charts with a more detailed scale $(1: 5000,1: 10000$ or $1: 25000$ as available) were used for the analysis of these areas. The study areas were: Costa Oriental del Lago de Maracaibo (eastern coast of Maracaibo Lake); Costa Oriental del Estado Falcón (eastern coast of Falcón State); Región Barlovento (windward region, including Cape Codera up to the Laguna de Tacarigua National Park); BarcelonaPuerto La Cruz-Guanta; and Playa El Agua and Bahía de Juangriego at Isla de Margarita.

\subsection{Scenarios used}

\subsubsection{Socioeconomic scenario}

Projections on population growth at the national level were based on data for the 1950 to 1990 period published by the Oficina Central de Estadística e Informática (OCEI) of Venezuela. These data were used to calculate an average geometric population growth rate by means of the equation:

$$
r=\left[\left(P_{0} / P_{\mathrm{f}}\right)^{1 / t}-1\right] \times 100
$$

where $r$ is the geometric population growth rate $(\%)_{i} P_{0}$ is the initial population; $P_{\mathrm{f}}$ is the final population; and $t$ is the year for which the projection is performed.

The population was then projected through the year 2100 , assuming a $3.3 \%$ constant growth rate. The average geometric population growth rate for each area was also calculated. The population of the area under consideration, which was projected through 2100 , corresponded to the 1950 to 1990 census period. The socioeconomic scenario developed indicates that, at the national level, the 2100 population (64.4 million people) will be almost 3 times the 1990 population (19.7 million people). The rate of growth for the subsequent years is expected to be lower.

Gross Domestic Product (GDP) values were obtained from publications of the Banco Central de Venezuela (BCV 1994). In order to estimate the current and future contribution to the GDP in the study areas and to project this value at the national level through the year 2100 , the average GDP per capita was calculated for each activity sector and the result was multiplied by the estimated population as follows:

$$
\mathrm{GDP}_{e}=X \cdot P_{\mathrm{e}}
$$

where GDP $\mathrm{G}_{\mathrm{e}}$ is the estimated Gross Domestic Product; $X$ is the average per-capita GDP in the different eco- nomic activity sectors; and $P_{\mathrm{e}}$ is the population estimated through the year to be assessed. The GDP shows a growth trend between 1990 (USS 2813.65 million) and 2100 (US\$ 14657.25 million), with a slow interannual increase (BCV 1994). The data indicate that, in spite of the economic constraints of the country, the productivity of the various sectors is likely to grow.

\subsubsection{Sea-level rise scenarios}

Two eustatic sea-level rise scenarios for the year 2100 were considered: $0.5 \mathrm{~m}$ (low) and $1.0 \mathrm{~m}$ (high), with special attention paid to the former (IPCC 1995).

Records of the national tide-gauge stations do not cover a period long enough to allow for an analysis of sea-level trends. Therefore, the eustatic scenarios were directly applied as sea-level rise scenarios at each of the study areas.

It was assumed that a new position of the coastline, and consequently a loss of land, would result from the conditions of the sea-level rise scenarios. A coastal recession model (Hands 1983, Nicholls \& Leatherman 1994, Nicholls et al. 1994) was applied to determine the amount of land loss for the 5 study areas.

The eastern coast of Maracaibo Lake is subject to subsidence. However, this phenomenon could not be fully analyzed in this study due to the lack of recent records. The first signs of subsidence were observed after the beginning of oil production in 1929. The highest subsidence rates recorded during the past few years range between $10 \mathrm{~cm} \mathrm{yr}^{-1}$ at Bachaquero and Tía Juana and $20 \mathrm{~cm} \mathrm{yr}^{-1}$ at Lagunillas. The accumulated subsidence between 1925 and 1994 is $5.45 \mathrm{~m}$. Since subsidence has increased to an average rate of $10 \mathrm{~cm}$ $\mathrm{yr}^{-1}$ it has become necessary to progressively increase the height of the dikes ( $2.5 \mathrm{~m}$ average height) as well as their length (approximately $48 \mathrm{~km}$ ).

The substantial oil investments made in the area, as well as the population of the urban centers located nearby, is therefore at risk.

\subsection{Socioeconomic analysis}

\subsubsection{Population}

An analysis of demographic issues was also carried out (OCEI 1991, 1994). The areas determined as vulnerable were those located below $0.5 \mathrm{~m}$ over mean sea level and having a population and infrastructure at risk. Thus, in most cases, only a portion of the urban areas at the study sites would be located within the sector defined as vulnerable. Therefore, an impacted population, comprising the entire population of the urban 
centers having a portion of their population at risk, was also considered as an indicator of vulnerability.

The type and number of buildings in the urban areas along the coast were estimated on the basis of land and marine field surveys, censuses of population and districts (OCEI 1991, 1994) and aerial photographs. The population at risk in the 5 study areas was estimated by multiplying the average number of persons per household (OCEI 1991) by the number of occupied houses. The population at risk through 2100 was also estimated.

\subsubsection{Land use}

The information needed to estimate the land use areas and patterns was obtained from urban management maps at scales of $1: 10000$ and 1:5000, produced by the Ministerio de Desarrollo Urbano (Ministry of Urban Development), and state land management maps (at a 1:250000 scale) and land management plans (at a 1:25000 scale), produced by the Ministerio del Ambiente y los Recursos Naturales Renovables (Ministry of the Environment and Natural Resources).

\subsubsection{Capital value}

Capital value is defined as the total value of land plus the existing infrastructure (IPCC 1992). The capital value was estimated on the basis of a survey of land prices in each study area by interviewing local real estate agents, experts and regional authorities. The projection through 2100 was made by multiplying the current capital value times the estimated annual inflation rate for that same year. This rate was considered linear in order to simplify the calculations.

The value of industrial infrastructure (FIV 1993), tourist infrastructure (CORPOTURISMO 1995), houses (OCEI 1991), communication infrastructure (MTC 1992) and fish processing infrastructure (MAC 1994) was also estimated.

In the case of the oil industry, only some of the costs were included due to the difficulty of obtaining more complete information. Therefore, the capital value used for oil infrastructure is considered to be underestimated.

An estimate of the capital value at risk was obtained on the basis of the information compiled and projected to 2100 . The current problems resulting from economic instability, exchange parity and inflation rates are sources of bias for this projection. Fluctuations in market values were not taken into account.

The economic value associated with the high biodiversity in coastal lagoons, coral reefs and wetlands was not taken into account due to the lack of information required for applying the IPCC (1990) methodology.

\subsection{Land at risk}

An analysis of coastal geomorphology was performed on the basis of the existing literature, particularly COPLANARH (1970) and Volonté \& Arismendi (1995), as well as of aerial photographs.

Additionally, information was collected during field surveys. A 'transit level' (Martínez et al. 1987), which is a simple and inexpensive piece of equipment, was used to take measurements every $300 \mathrm{~m}$ for the assessment of profiles at the study sites.

The most important mechanism of land loss according to the geomorphological characteristics of the area was then determined: erosion on sandy beaches and low reefs; inundation in lowlands (particularly wetlands, marshes, salt marshes and estuaries); and no land loss on reefs and rocky coasts.

The area of the land exposed to inundation was estimated on the basis of the simple inundation concept using a polar planimeter. The Brunn Rule, modified by Hands (1983) as described in Nicholls \& Leatherman (1994) and Nicholls et al. (1994), was applied to calculate land loss due to erosion:

$$
R=S G L /\left(B+h_{x}\right)
$$

where $R$ is the recession due to sea-level rise $S$, and $G$ is the proportion of erodible material that remains in the active profile, which is conventionally considered as $100 \%$. Due to the absence of well-developed dunes along the study coast, the height of the dune $(B)$ was taken as the distance between mean sea level and the closest infrastructure or vegetation. The depth of closure $\left(h_{x}\right)$ for the current conditions was estimated using bathymetric charts due to the lack of continuous records on sediment transport and wave pattern along the coast. The active profile width $L$ was also measured on the charts.

The depth of closure is the variable most difficult to estimate due to the lack of sediment transport data. Therefore, 2 different estimates of the depth of closure were used $\left(d_{L, 1}\right.$ and $\left.d_{L, 100}\right)$ and were related to the current depth of closure (Nicholls et al. 1994). The term $d_{L, 1}$ is the depth of closure for 1 yr and $d_{L, 100}$ is the depth of closure for $100 \mathrm{yr}$. According to Nicholls et al. (1994), it may be assumed that $d_{L, 100}$ is 1.75 times $d_{L, 1}$. Since the data required for estimating $d_{L, 1}$ (i.e. the maximum depth at which the inshore and offshore sediment transport are the highest and the average significant wave height and its standard deviation) are not available, a depth of closure of $5 \mathrm{~m}$ was used for all the study areas except for Isla de Margarita. In that case, a value of $1 \mathrm{~m}$ was used (Volonté \& Arismendi 1995). The $5 \mathrm{~m}$ and $1 \mathrm{~m}$ values were adopted since they represent the highest depth at which the waves affect the bottom, with a relatively 
stable slope. Thus, these 2 values provide a range of estimates of land loss due to erosion.

\subsection{River inundation}

The study also includes an assessment of the areas along the rivers which may be subject to inundation as a consequence of sea-level rise. This assessment was performed by estimating the potentially inundated areas on the basis of topographic, geomorphologic and hydrologic information.

\subsection{Groundwater}

The main groundwater sources were identified on maps, and the existing data on the physical and chemical water characteristics were compiled.

\subsection{Response strategies}

Four response options to sea-level rise were evaluated:

No Protection: In this case, no coastal protection measures would be adopted. Therefore, land and capital loss would be the highest, but the protection cost would be null.

Existing Protection: The existing protection option assumes that the coastal infrastructure will be reconstructed at a higher level in the event of sea-level rise. The type and extent of the existing coastal protection were assessed and the cost of raising such infrastructure was estimated. The IPCC indicators were used in this case due to the lack of values at the national level.

Important Areas Protection: This option addresses the protection of industrial, residential and tourist areas, including maintenance of tourist beaches, raising of coastal infrastructure and road protection.

Total Protection: In addition to the protection of important areas, it is assumed that all coastal areas with a population density above 10 people $\mathrm{km}^{-2}$ will be protected. All the coastal areas studied have a higher population density. The cost of constructing dikes along the unprotected coast would then be added to the cost of Important Areas Protection. The reference costs used by Arismendi \& Volonté (1992) for the construction of dikes along low coasts highly exposed to wave action (US\$ 0.5 million) as well as for dikes along high coasts were applied in this case.

\section{RESULTS}

\subsection{Socioeconomic and biophysical characterization}

The socioeconomic information and projections of it through 2100 are presented in Table 1. A synthesis of the most conspicuous biophysical characteristics is presented in Table 2 .

\subsection{Land at risk}

Values of land loss due to erosion and inundation are presented in Table 3 . Coastline recession would be $246 \mathrm{~m}$ at Costa Oriental del Lago de Maracaibo, $116 \mathrm{~m}$ at Barcelona-Puerto La Cruz-Guanta, $61 \mathrm{~m}$ at Cabo Codera-Parque Nacional Laguna de Tacarigua, $51 \mathrm{~m}$

Table 1. Sociodemographic characteristics of the study areas in Venezuela. Popul.. population; Dens.: density; Imp.: impacted; Occ.: occupied; Unocc. unoccupied; hshld: household, Comm.: commercial; Ind.: Industry. Based on data published by OCEI 1990

\begin{tabular}{|c|c|c|c|c|c|c|c|c|c|c|c|c|}
\hline \multirow{2}{*}{ Study area } & \multicolumn{3}{|c|}{ Total area involved } & \multicolumn{4}{|c|}{ Vulnerable area } & \multicolumn{5}{|c|}{ Infrastructures (no.) } \\
\hline & Popul. & $\begin{array}{c}\text { Area } \\
\left(\mathrm{km}^{2}\right)\end{array}$ & $\begin{array}{c}\text { Dens. } \\
\left(\mathrm{km}^{-2}\right)\end{array}$ & $\begin{array}{l}\text { Pop } \\
\text { Imp. }\end{array}$ & At risk & $\begin{array}{l}\text { Area } \\
\left(\mathrm{km}^{2}\right)\end{array}$ & $\begin{array}{l}\text { Dens. } \\
\left(\mathrm{km}^{-2}\right)\end{array}$ & $\begin{array}{c}\text { Occ. } \\
\text { houses }\end{array}$ & $\begin{array}{l}\text { Unocc. } \\
\text { houses }\end{array}$ & $\begin{array}{l}\text { Avg no. } \\
\text { pers./ } \\
\text { hshld }\end{array}$ & $\begin{array}{l}\text { Comm. } \\
\text { activities } \\
\text { at risk }\end{array}$ & $\begin{array}{l}\text { Ind. } \\
\text { at risk }\end{array}$ \\
\hline $\begin{array}{l}\text { Costa Oriental del } \\
\text { Lago de Maracaibo }\end{array}$ & 483690 & 8234 & 59 & 241826 & 20784 & 40.1 & 518 & 3997 & 138 & 5.2 & 601 & 35 \\
\hline $\begin{array}{l}\text { Costa Oriental } \\
\text { de Fälcón }\end{array}$ & 34926 & 2201 & 16 & 22232 & 17044 & 47.3 & 360 & 3216 & 2703 & 5.3 & 469 & 9 \\
\hline $\begin{array}{l}\text { Cabo Codera- } \\
\text { Parque Nacional }\end{array}$ & 69103 & 2419 & 29 & 18847 & 6325 & 37.9 & 167 & 1375 & 2026 & 4.6 & 360 & 5 \\
\hline $\begin{array}{l}\text { Laguna de Tacarigua } \\
\text { Barcelona- } \\
\text { Pto La Cruz-Guanta }\end{array}$ & 434084 & 178 & 1071 & 401539 & 5417 & 3.5 & 1535 & 1022 & 123 & 5.3 & 63 & - \\
\hline \multicolumn{13}{|l|}{ Isla de Margarita } \\
\hline Juan Griego & 62732 & 66 & 950 & 13024 & 653 & 1.4 & 466 & 121 & 97 & 5.4 & - & - \\
\hline
\end{tabular}


at Costa Oriental de Falcón, $30 \mathrm{~m}$ at Playa El Agua and $14 \mathrm{~m}$ at Juan Griego.

\subsection{Response strategies}

\subsubsection{No Protection}

In this case, all the land in the study areas $\left(131.61 \mathrm{~km}^{2}\right)$ as well as all wetlands would be lost.

\subsubsection{Existing Protection}

The cost of raising the existing coastal infrastructure, namely breakwaters, groins, dikes and ports, as well as of revetment at each of the study areas, was evaluated. As indicated in Table 4, the total cost of protection is US $\$ 14984$ million. According to the calculations performed, $124.74 \mathrm{~km}^{2}$ of land $195 \%$ of the total study area) would be lost should this option be adopted.

Table 2. Synthesis of biophysical characteristics of the study areas in Venezuela

\begin{tabular}{|c|c|c|c|c|c|c|c|c|}
\hline \multirow[t]{2}{*}{ Type of data } & \multirow[t]{2}{*}{ Units } & \multicolumn{6}{|c|}{ Study area } & \multirow[t]{2}{*}{ Subtotal } \\
\hline & & $\begin{array}{c}\text { Costa Oriental } \\
\text { Lago de } \\
\text { Maracaibo }\end{array}$ & $\begin{array}{c}\text { Costa } \\
\text { Oriental } \\
\text { Falcón }\end{array}$ & $\begin{array}{c}\text { Cabo Codera } \\
\text { Laguna de } \\
\text { Tacarigua }\end{array}$ & $\begin{array}{l}\text { Barcelona- } \\
\text { Puerto La } \\
\text { Cruz-Guanta }\end{array}$ & $\begin{array}{l}\text { Isla de } N \\
\text { Playa } \\
\text { El Agua }\end{array}$ & $\begin{array}{l}\text { argarita } \\
\text { Juan } \\
\text { Griego }\end{array}$ & \\
\hline Extent of marine coasts & $\mathrm{km}$ & 85.1 & 172.8 & 78.5 & 50.65 & 3.16 & 4.32 & 343.88 \\
\hline Extent of lacustrine coast & ts $\mathrm{km}$ & 141.1 & & & & & & 141.1 \\
\hline $\begin{array}{l}\text { Total extent of the coasts } \\
\text { under study }\end{array}$ & $\mathrm{km}$ & 229.1 & 172.8 & 154 & 50.65 & 3.16 & 4.32 & 563.38 \\
\hline Coastal area under study & $\mathrm{km}^{2}$ & 40.1 & 47.3 & 37.9 & 3.53 & 1.4 & 0.9 & 131.13 \\
\hline \multicolumn{9}{|l|}{ Types of marine coast } \\
\hline High & $\mathrm{km}$ & 17 & 9.5 & & 29.80 & 0.15 & 2.9 & 29.55 \\
\hline Low & $\mathrm{km}$ & 212.1 & 163.3 & 154 & 20.85 & 3.05 & 1.42 & 533.87 \\
\hline Total & $\mathrm{km}$ & 229.1 & 172.8 & 154 & 50.65 & 3.2 & 4.32 & 563.42 \\
\hline \multicolumn{9}{|c|}{ Extent of coastal infrastructure } \\
\hline Dikes-embankments & $\mathrm{km}$ & 48 & 0.2 & 0.2 & 4.19 & ' & 0.07 & 52.66 \\
\hline Breakwaters & $\mathrm{km}$ & 2.7 & 0.16 & 0.18 & 1.56 & · & • & 4.6 \\
\hline Revetment & $\mathrm{km}$ & 1.2 & & & 1.5 & $\cdot$ & $\cdot$ & 2.7 \\
\hline Groins & $\mathrm{km}$ & 4.9 & 0.73 & 0.24 & 1.05 & $\cdot$ & 0.24 & 7.16 \\
\hline \multicolumn{9}{|l|}{ Subsidence } \\
\hline Induced & $\mathrm{cm} y \mathrm{r}^{-1}$ & 8 & $\cdot$ & * & • & • & $\cdot$ & 8 \\
\hline Area & $\mathrm{km}^{2}$ & 85 & $\cdot$ & $\cdot$ & $\cdot$ & $\cdot$ & $\cdot$ & 85 \\
\hline \multicolumn{9}{|l|}{ Groundwater } \\
\hline Average depth & $\mathrm{m}$ & 121.36 & 84.95 & 59 & 39 & 31.7 & • & \\
\hline Average static level & $\mathrm{m}$ & 21 & 45 & 9.6 & 10 & 21.5 & · & \\
\hline Average dynamic level & $\mathrm{m}$ & 40.73 & 12.5 & 16 & 15 & $\cdot$ & $\cdot$ & \\
\hline Flow & $15^{-1}$ & 4.6 & 4.35 & 12 & 11 & 1 & $\cdot$ & 32.95 \\
\hline \multicolumn{9}{|l|}{ Average tide elevation } \\
\hline Marine coast & $\mathrm{m}$ & 1.4 & 0.3 & 0.3 & 0.23 & 0.3 & 0.25 & \\
\hline Lacustrine coast & $\mathrm{m}$ & 0.7 & & & & & & \\
\hline \multicolumn{9}{|c|}{ Estimate of area subject to river inundation } \\
\hline Average & $\mathrm{km}^{2}$ & $\cdots$ & 35 & 103.46 & $\cdot$ & $\cdot$ & $\cdot$ & 138.46 \\
\hline \multicolumn{9}{|l|}{ Wave height } \\
\hline Marine coast & $\mathrm{m}$ & $0.30-1.50$ & $0.70-1.20$ & $0.50-0.90$ & 0.3 & $\cdots$ & $\cdots$ & \\
\hline \multicolumn{9}{|l|}{ Sediment load } \\
\hline Transport & $\mathrm{m}^{3} \mathrm{yr}^{-1}$ & 130000 & 130000 & 150000 & 50000 & $\cdots$ & $\cdots$ & 460000 \\
\hline \multicolumn{9}{|l|}{ Currents } \\
\hline Marine coast & $\mathrm{cm} \mathrm{s}^{-1}$ & $\cdots$ & $2.00-20.00$ & $30.00-10.00$ & $6.00-25.00$ & $\cdots$ & $\cdots$ & \\
\hline Coastal lagoons & $\mathrm{km}^{2}$ & 201.4 & 14 & 207.5 & $\cdot$ & $\cdot$ & $\cdot$ & 422.9 \\
\hline Mangroves & $\mathrm{km}^{2}$ & 40.6 & 35 & 54.3 & $\cdots$ & $\cdot$ & $\cdot$ & 129.9 \\
\hline Coral reefs & $\mathrm{m}$ & $\cdot$ & 777 & $\cdots$ & 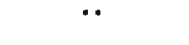 & • & $\cdot$ & 777 \\
\hline Protected areas & $\mathrm{km}^{2}$ & 24208 & 43915 & 39100 & 94935 & • & $\cdot$ & 202158 \\
\hline
\end{tabular}


Table 3. Land loss (in $\mathrm{km}^{2}$ ) due to erosion and inundation for the study areas in Venezuela

\begin{tabular}{|c|c|c|c|c|c|c|}
\hline \multirow{3}{*}{ Study area } & \multicolumn{4}{|c|}{ Erosion scenarios } & \multirow{2}{*}{\multicolumn{2}{|c|}{$\begin{array}{l}\text { Inundation } \\
\text { scenarios }\end{array}$}} \\
\hline & \multicolumn{2}{|c|}{ Low } & \multicolumn{2}{|c|}{ High } & & \\
\hline & $0.5 \mathrm{~m}$ & $1.0 \mathrm{~m}$ & $0.5 \mathrm{~m}$ & $1.0 \mathrm{~m}$ & $0.5 \mathrm{~m}$ & $1.0 \mathrm{~m}$ \\
\hline Costa Oriental del Lago de Maracaibo & 11.2 & 17.19 & 17.84 & 18.58 & 13.19 & 21.52 \\
\hline Costa Oriental de Falcón & 3.34 & 6.69 & 5.47 & 10.86 & 22.62 & 32.76 \\
\hline Cabo Codera-Parque Nacional Laguna de Tacarigua & 5.22 & 9.59 & 8.38 & 15.43 & 15.43 & 21.18 \\
\hline Barcelona-Puerto La Cruz-Guanta & 0.24 & 0.65 & 0.38 & 1.05 & 1.35 & 2.21 \\
\hline \multicolumn{7}{|l|}{ Isla de Margarita } \\
\hline Playa El Agua & 0.04 & 0.06 & 0.1 & 0.28 & - & - \\
\hline Juan Griego & 0.03 & 0.06 & 0.74 & 0.8 & 0.04 & 0.07 \\
\hline
\end{tabular}

Table 4. Protection costs for coastal sites in Venezuela under a $0.5 \mathrm{~m}$ sea-level rise (in millions of US\$)

\begin{tabular}{|c|c|c|c|}
\hline Study area & $\begin{array}{l}\text { Beach maintenance }(A) \\
(\text { per } \mathrm{km})\end{array}$ & $\begin{array}{c}\text { Raising of } \\
\text { infrastructure (B) }\end{array}$ & Dikes $(\mathrm{C})$ \\
\hline Costa Oriental del Lago de Maracaibo & - & 6597 & - \\
\hline Costa Oriental de Falcón & 10.555 & 897 & 0.315 \\
\hline Cabo Codera-Parque Nacional Laguna de Tacarigua & 12.375 & 2986 & 2.15 \\
\hline Barcelona-Puerto La Cruz-Guanta & 0.355 & 4206 & - \\
\hline \multicolumn{4}{|l|}{ Isla de Margarita } \\
\hline Playa El Agua & 0.845 & - & - \\
\hline Juan Griego & - & 298.5 & - \\
\hline Subtotal & 24.13 & 14984.5 & 2.465 \\
\hline
\end{tabular}

\subsubsection{Important Areas Protection}

After geomorphological characterization of the study areas we selected 6 sites, covering $22 \mathrm{~km}$, for beach maintenance. The cost of sand suggested by the IPCC (1990) (US\$ $5 \mathrm{~m}^{-3}$ ) was used for calculations (Table 4). The estimated cost of beach nourishment is US\$24.13 million. The cost of Important Areas Protection plus raising and maintenance add up to a total of over USS 15000 million. If this type of protection were applied the loss of land would be $86.16 \mathrm{~km}^{2}$, which represents $65.71 \%$ of the total study area.

\subsubsection{Total Protection}

The cost of protecting the unprotected coast with dikes would add to the cost of Important Areas Protection (Table 4). This would amount to an additional US\$ 2.5 million.

If the Total Protection option is adopted, $59.30 \mathrm{~km}^{2}$ of land will be lost. This represents $45.22 \%$ of the total study area. Therefore, land loss in this case would be lower than in the cases of the other protection options.

\subsection{River inundation assessment}

The estimated area which is potentially subject to river inundation at the Costa Oriental de Falcón is $35 \mathrm{~km}^{2}$. At Cabo Codera-Parque Nacional Laguna de Tacarigua the area exposed to river inundation is estimated at $103.46 \mathrm{~km}^{2}$. At Barcelona-Puerto La CruzGuanta, a disruption of the drainage system in the urban areas located within or close to the inundated areas is foreseen. This would be due to the mild slope of the drainage system and to the failure to implement anticipated measures.

In conclusion, about $138.51 \mathrm{~km}^{2}$ are likely to be subject to river inundation. This area is underestimated due to basic gaps in the information.

\section{DISCUSSION}

As regards land losses derived from a $0.5 \mathrm{~m}$ sealevel rise (Fig. 1), it was observed that all study sites are more vulnerable to inundation than to erosion. At all sites except for Isla de Margarita, more than 32\% of the area is at risk of inundation, while land loss due 
to erosion would vary from $27.9 \%$ (Costa Oriental del Lago Maracaibo) to $6.8 \%$ (Barcelona-Puerto La CruzGuanta)

According to the detailed inventory of existing protection carried out, there are substantial investments in coastal infrastructure at risk (US\$ 1865.85 million). They include ports, dikes, breakwaters, groins, and industrial and tourist structures. The capital values at risk are also substantial (US $\$ 5000$ million).

The estimated costs of the protection options assessed are considerable: beach maintenance (US\$ 24.13 million); raising of infrastructure (USS 14984 million) and additional dikes (US\$ 2.50 million).

Results from the vulnerability analysis at each study area are shown in Table 5. Land loss estimates indicate high potential erosion and inundation values at Costa Oriental del Lago de Maracaibo, in addition to the highest

\section{Costa Oriental del Lago de Maracaibo}

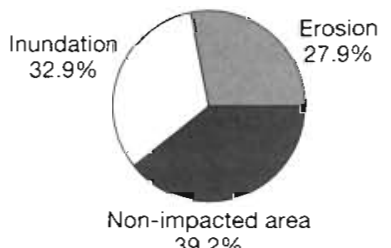

$39.2 \%$

Cabo Codera-P.N. Laguna de Tacarigua

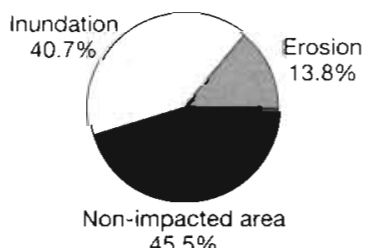

Isla de Margarita: Playa El Agua



Erosion

$2.9 \%$

Fig. 1. Potential land loss at each study site

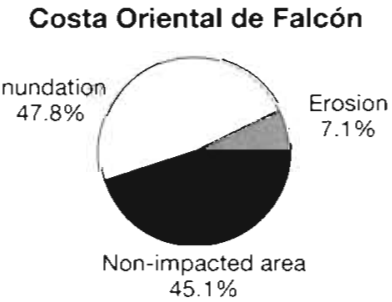

Barcelona-Puerto La Cruz-Guanta



Isla de Margarita: Juan Griego

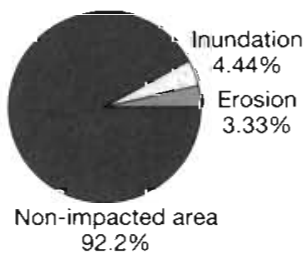

Table 5. Vulnerability analysis for Venezuela and selected coastal regions. GDP = Gross Domestic Product; $L E=$ land loss due to erosion; $\mathrm{LI}=$ land loss due to inundation; $\mathrm{CVR}=$ capital value at risk; $\mathrm{ECPV}=$ existing coastal protection value IRC $=$ infrastructure raising cost $(1 \mathrm{~m}) ; \mathrm{TPC}=$ total protection cost

\begin{tabular}{|c|c|c|c|c|c|c|c|c|}
\hline \multirow[t]{4}{*}{ Variable } & \multirow[t]{4}{*}{ Venezuela } & \multicolumn{6}{|c|}{ Study area } & \multirow{4}{*}{$\begin{array}{c}\text { Total for } \\
\text { study } \\
\text { areas }\end{array}$} \\
\hline & & Costa Oriental & Costa & Cabo Codera & Barcelona & Isla de I & argarita & \\
\hline & & Lago de & Oriental & Laguna de & Puerto La & Playa & Juan & \\
\hline & & Maracaibo & Falcón & Tacarigua & Cruz Guanta & El Agua & Griego & \\
\hline \multicolumn{9}{|l|}{ Present values (1995) } \\
\hline Area $\left(\mathrm{km}^{2}\right)$ & 916445.00 & 40.10 & 47.30 & 37.90 & 3.53 & 0.90 & 1.40 & 131.13 \\
\hline Population & 18105265 & 20784 & 17044 & 6325 & 5417 & 0 & 653 & 50223 \\
\hline Density (pers. $\mathrm{km}^{-2}$ ) & 20 & 518 & 360 & 167 & 1535 & 0 & 466 & \\
\hline $\operatorname{GDP}\left(10^{6} \mathrm{US} \$\right)$ & 2813.65 & 70.43 & 7.33 & 10.35 & 24.97 & 2.07 & 3.09 & \\
\hline $\mathrm{LE}\left(\mathrm{km}^{2}\right)$ & & 11.20 & 3.34 & 5.22 & 0.24 & 0.04 & 0.03 & 20.07 \\
\hline L.I $\left(\mathrm{km}^{2}\right)$ & & 13.19 & 22.62 & 15.43 & 1.35 & 0.00 & 0.04 & 52.63 \\
\hline CVR $\left(10^{9}\right.$ US $\left.\$\right)$ & & 0.16 & 0.00 & 0.02 & 0.07 & 0.00 & 0.00 & 0.25 \\
\hline ECPV $\left(10^{9}\right.$ US\$ $)$ & & 0.82 & 0.01 & 0.03 & 0.06 & 0.00 & 0.00 & 0.92 \\
\hline $\operatorname{IRC}\left(10^{9}\right.$ US $\left.\$\right)$ & & 6.59 & 0.90 & 2.98 & 4.20 & 0.00 & 0.30 & 14.97 \\
\hline $\operatorname{TPC}\left(10^{9}\right.$ US $\left.\$\right)$ & & 6.59 & 0.90 & 2.98 & 4.20 & 0.00 & 0.30 & 14.97 \\
\hline \multicolumn{9}{|c|}{ Projected values $(2100)$} \\
\hline Area $\left(\mathrm{km}^{2}\right)$ & 916445.00 & 40.10 & 47.30 & 37.90 & 3.53 & 0.90 & 1.40 & 131.13 \\
\hline Population & 34042109 & 33774 & 27230 & 11310 & 16170 & 0 & 1290 & 89774 \\
\hline Density (pers. $\mathrm{km}^{-2}$ ) & 37 & 842 & 576 & 298 & 4581 & 0 & 922 & \\
\hline $\operatorname{GDP}\left(10^{6} \mathrm{US} \$\right)$ & 14657.25 & 341.64 & 35.54 & 49.87 & 120.95 & 14.91 & 10.32 & \\
\hline $\operatorname{LE}\left(\mathrm{km}^{2}\right)$ & & 17.19 & 6.69 & 9.59 & 0.65 & 0.06 & 0.06 & 34.24 \\
\hline LI $\left(\mathrm{km}^{2}\right)$ & & 21.52 & 32.76 & 21.18 & 2.21 & 0.00 & 0.07 & 77.74 \\
\hline $\operatorname{CVR}\left(10^{12}\right.$ US $\left.\$\right)$ & & 0.03 & 0.00 & 0.00 & 0.01 & 0.00 & 0.00 & 0.04 \\
\hline ECVP $\left(10^{12}\right.$ US\$) & & 115.91 & 1.70 & 4.40 & 9.00 & 0.50 & 0.00 & 131.51 \\
\hline $\operatorname{IRC}\left(10^{12}\right.$ US\$ $)$ & & 0.78 & 0.11 & 0.35 & 0.50 & 0.00 & 0.04 & 1.78 \\
\hline TPC $\left(10^{12}\right.$ US\$ $)$ & & 0.78 & 0.11 & 0.35 & 0.50 & 0.00 & 0.04 & 1.78 \\
\hline
\end{tabular}


capital value of all the study areas $\left(0.16 \times 10^{9}\right)$. Additionally, if the value of replacing the oil industry (estimated at about USS 10000 million) is taken into account, this area can be deemed as the most vulnerable to the effects of sea-level rise.

The areas may be ranked, in decreasing order of sensitivity, as follows: Costa Oriental del Lago de Maracaibo, Barcelona-Puerto La Cruz-Guanta, Cabo Codera-Parque Nacional Laguna de Tacarigua, Costa Oriental del Estado Falcón, Isla de Margarita.

However, if the cost of different response options and the estimated national Gross Domestic Product of US\$ 2813 million are considered, it is concluded that the country would not be able to afford the costs of implementing any of the protection measures above.

From another point of view it can be expected, in theory, that most coastal biotic systems will be able to adapt to the extreme conditions derived from a gradual increase in sea level. Other groups will tend to migrate inland according to their adaptive response capability and flexibility. A more detailed assessment of the responses of mangroves and coral reefs is required, since they are considered to be key ecosystems due to their rich biodiversity.

\section{CONCLUSIONS}

It can be concluded that most of the area of the selected study sites is highly vulnerable to sea-level rise. This is due to their geomorphological characteristics, since they are low coastal plains. The vulnerability could be increased by factors such as subsidence and anthropogenic alterations related to water supply (from rivers and groundwater) as well as sediment release. These issues should be studied in detail.

Global sea-level rise would also cause an increase in the water level at the Lago de Maracaibo. Therefore, it would be necessary to gradually relocate the vulnerable populations into safer areas and strongly discourage the settlement of new inhabitants.

The ranking of critical zones and a detailed evaluation of costs would be required. Further research is also needed with regard to certain issues, such as cost indices the IPCC (1990) indices were used in this study], national sediment balance and an integrated assessment of coastal dynamics.

The establishment of a formal National Coastal Management Program is also required. This would serve as a basis for the actions of the Ministerio del Ambiente $y$ de Ios Recursos Naturales Renovables (Ministry of the Environment and Natural Resources) and the relevant Concejos Municipales (Municipal Councils).

Further, it is necessary to develop a unified coastal zone data collection system for the conduct of historical analyses of the elements required for improving knowledge on vulnerable ecosystems.

Acknowledgements. The authors acknowledge the U.S. Country Studies Program for the technical and financial assistance provided to conduct this study, as well as General Coordinator Martha Perdomo for her helpful comments.

\section{LITERATURE CITED}

Arismendi J, Volonté C (1992) The impact of sea level rise on the coastline of Venezuela. In: Global climate change and the rising challenge of the sea. Proceedings of the International Workshop held on Isla de Margarita, Venezuela. Coastal Zone Management Subgroup, Response Strategies Working Group, Intergovernmental Panel on Climate Change (IPCC), Caracas, p 453-471

BCV (Banco Central de Venezuela) (1994) Informe Anual. BCV, Caracas

COPLANARH (Comisión del Plan Nacional de Aprovechamiento de los Recursos Hidráulicos) (1970) Inventario Nacional de Tierras, Región 7, Subregión 7B. COPLANARH, Caracas

CORPOTURISMO (1995) Registros Infraestructura Turística. CORPOTURISMO, Caracas

FIV (Fondo de Inversiones de Venezuela) (1993) Privatización. FIV, Caracas

Hands EB (1983) The Great Lakes as a test model for profile responses to sea level changes. In: Komar PD (ed) Handbook of coastal processes and erosion. CRC Press, Boca Raton, FL, p 167-189

IPCC (Intergovernmental Panel on Climate Change) (1990) Strategies for adaptation to sea level rise. Coastal Zone Management Subgroup Report, Working Group III Report. Ministry of Transport, Public Works and Water Management, Directorate General Rijkswaterstaat, 'Tidal Waters Division, Rijkswaterstaat

IPCC (Intergovernmental Panel on Climate Change) (1992) Global climate change and the rising challenge of the sea. Report of the Coastal Zone Management Subgroup, Response Strategies Working Group. Ministry of Transport, Public Works and Water Management, Directorate General Rijkswaterstaat, Tidal Waters Division, Rijkswaterstaat

IPCC (Intergovernmental Panel on Climate Change) (1995) Impacts, adaptation and mitigation of climate change: Scientific-technical analyses. Contribution of Working Group II to the Second Assessment Report of the IPCC. Houghton JT, Meira Filho LG, Callander BA, Harris N, Kattenberg A, Maskell K (eds). Cambridge University Press, Cambridge

MAC (Ministerio de Agricultura y Cría) (1994) Registros sobre producción pesquera anual. Dirección de Pesca, Caracas

Martínez J, Navarro T, Boldán A, Rosario M (1987) Cuantificación e interpretación de los procesos de acreciónerosión en la playa arenosa de El Hombre (Gran CanariaEspaña). Actas de la VII Reunión sobre el Cuaternario, Santander, España. AEQUA 3:227-230

MTC (Ministerio de Transporte y Comunicaciones) (1992) Nomenclator de carreteras. Dirección de Vialidad, Caracas

Nicholls RJ, Leatherman SP (1994) Sea-level rise and coastal management. In: McGregor D, Thompson D (eds) Geomorphology and land management in a changing environment. John Wiley and Sons, London (in press) 
Nicholls R, Leatherman S, Dennis K, Volonté C (1994) Impacts and responses to sea-level rise: qualitative and quantitative assessments. J Coast Res (Spec Iss) 14:26-43

OCEI (Oficina Central de Estadística e Informática) (1991) Tiempo de resultados $\mathrm{N}^{\circ} 1$. OCEI, Caracas
OCEI (Oficina Central de Estadística e Informática) (1994) Anuario $N^{\circ} 4$. OCEI, Caracas

Volonté C, Arismendi J (1995) Sea level rise and Venezuela: potential impacts and responses. J Coast Res 14 285-302 